\title{
The effectiveness of Lacanian analysis group therapy on empathy, social acceptance and social competence in adolescent girls in Tehran city: two months follow-up
}

\author{
Lila Hatam Tahrani Moghadam ${ }^{1}$, Maryam Mousavi Nike², Seyeed Kazem Malakouti \\ 1-Master of Clinical Psychology, Department of Psychology, Naser Khosro Institute of Higher Education, Saveh, \\ Iran (Corresponding Author). $\quad$ E-mail: hatamtehrani20@gmail.com \\ 2- Assistant professor, Department of Psychology, Naser Khosro Institute of Higher Education, Saveh, Iran.
}

Received: 13/06/2020

Accepted: 19/08/2020

\begin{abstract}
Introduction: The occurrence of significant changes in adolescence can affect empathy, acceptance and competence in adolescents. Therefore, psychoanalytic interventions are necessary for adolescent emotional and social adjustment.

Aim: The purpose of this study was to determine effectiveness of Lacanian analysis group therapy on empathy, social acceptance and social competence.

Method: This study was a research design was quasi-experimental with pretest-posttest and control group with two-month follow-up. The population of this study included all the female students' high school of Tehran city in year 2018-2019. In this study, 30 female students were considered as the sample size in two experimental groups (15 students) and control (15 students). The experimental group underwent 6 sessions Lacanian analysis group therapy 90 minutes and but control group received no intervention and remained in the waiting list. To collect data empathy scale Jolliffe and Farrington, social desirability scale of Marlowe- Crowne and social competence scale of Felner, Lease Phillips. Data analysis was performed using of covariance with SPSS 24.

Results: The findings showed that Lacanian analysis group therapy had a significant effect on emotional empathy $(\mathrm{F}=6.29)$, cognitive empathy $(\mathrm{F}=4.41)$, acceptance $(\mathrm{F}=5.36)$, cognitive competence $(\mathrm{F}=18.47)$, behavioral $(\mathrm{F}=20.99)$, emotional $(\mathrm{F}=4.34)$, motivational $(\mathrm{F}=17.54)$ in post-test and after a two month follows up $(\mathrm{P}<0.05)$.

Conclusion: Results highlight the importance of Lacanian analysis group therapy for empathy, social acceptance and social competence in adolescent girls and providing new perspectives in clinical interventions. So pay attention to the effectiveness of analysis group therapy in counseling and psychotherapy of teen girls has a special significance.
\end{abstract}

Keywords: Group therapy, Empathy, Social distance, Social competence

How to cite this article : Hatam Tahrani Moghadam L, Mousavi Nike M, Malakouti SK. The effectiveness of Lacanian analysis group therapy on empathy, social acceptance and social competence in adolescent girls in Tehran City: two months follow-up. Shenakht Journal of Psychology and Psychiatry. 2020; 7 (4): 105-121 .URL: http://shenakht.muk.ac.ir/article-1-915-en.pdf

Copyright $@ 2018$ the Author (s). Published by Kurdistan University of Medical Sciences. This is an open access article distributed under the terms of the Creative Commons Attribution-Non Commercial License 4.0 (CCBY-NC), where it is permissible to download, share, remix, transform, and buildup the work provided it is properly cited. The work cannot be used commercially without permission from the journal. 


\title{
اثربخشى كروه درماذى تحليلى لاكانى بر همدلى، يذيرش اجتماعى و كفايت اجتماعى: با بيكيرى دو ماهه
}

\author{
ليلا حاتم طهر انى مقدم'، مريم موسوى نيكك'، سيد كاظم ملكوتى \\ ا.كارشناس ارشد روانشناسى بالينى، گروه روانشناسى، مؤسسه آموزش عالى غير انتفاعى ناصر خسرو، ساوه، ايران (مولف مسئول). \\ ايميل:و hatamtehrani20@gmail.com \\ r. استاديار، كروه روانشناسى، مؤسسه آموزش عالى غير انتفاعى ناصر خسرو، ساوه، ايران.
}

مقدمه: وقوع تغييرات جشمخير در نوجوانى مى تو اند هملىى، بذيرش اجتماعى و كفايت اجتماعى نوجوانان را تحت الشعاع قرار دهد.

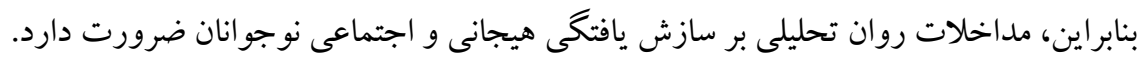
هدف: هدف از يزوهش حاضر تعيين اثربخشى گروه درمانى تحليلى لاكانى بر همدلى، يذيرش اجتماعى و كفايت اجتماعى بود. روش: روش ئزوهش نيمه آزمايشى با طرح بيش آزمون- بس آزمون و گروه كنترل با بيخيرى دو ماهه بود. در اين بزوهش جامعه

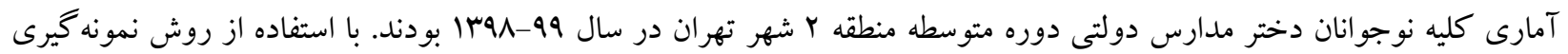

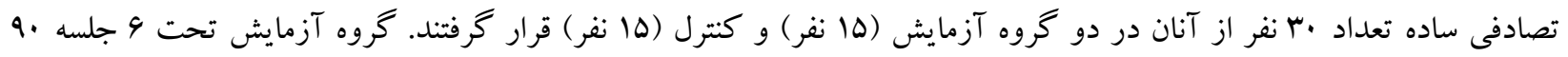

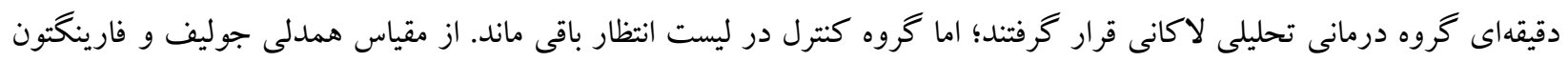

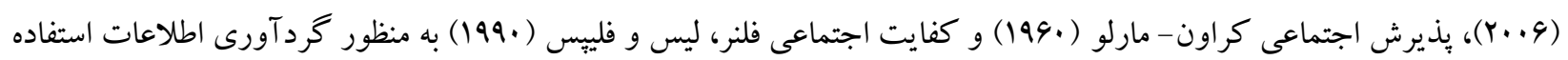

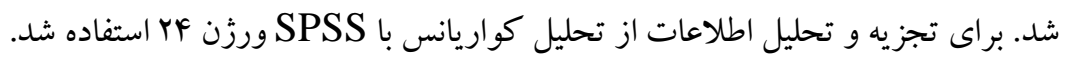

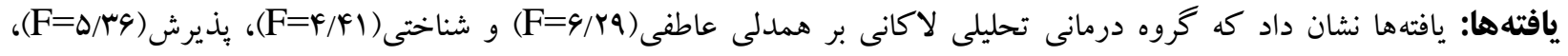
كفايت شناختى(

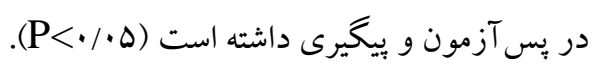

نتيجه كيرى: نتايج اين بزوهش اثربخشى گروه درمانى تحليلى لاكانى را در بهبود همدلى، بذيرش اجتماعى و كفايت اجتماعى

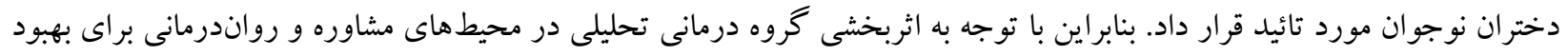

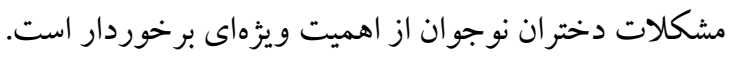
كليدوازهها: گروه درمانى تحليلى لاكانى، همدلى، يذيرش اجتماعى، كفايت اجتماعى 


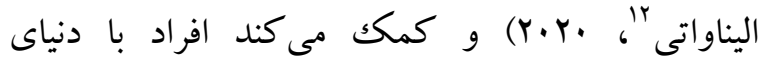

مقلدمه

اجتماعى خود بيوند برقرار كنند و با افزايش هوش آنس

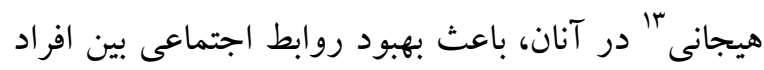

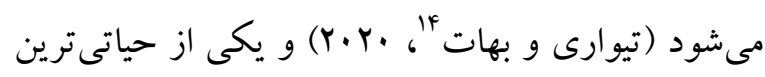

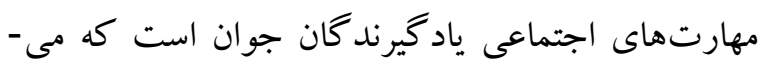
توان آن را رشد داد (موسويان، طلايى، فرادانش و ونسي

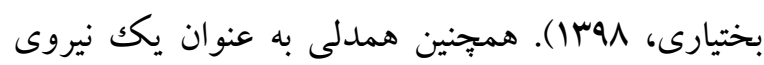
انخيزشى انسجام گروهى را در نوجوانان را بهبود بخشيده

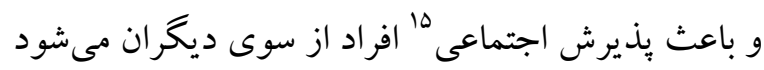

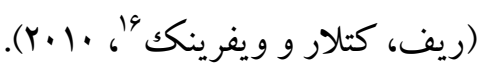
براساس نتايج يكك يُزوهش، نوجو انانى كه از همدلى قابل توجه در خودشان برخوردار هستند، از نغاه ديخران مقبولتر هستند و بذيرش اجتماعى بالايى در نزد ديخران

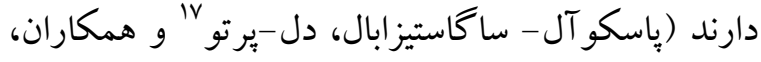
19.19). احساس ارزشمندى و پِذيرفته شدن از سوى همسالان و جامعه با عنوان يذيرش اجتماعى شناخته شده

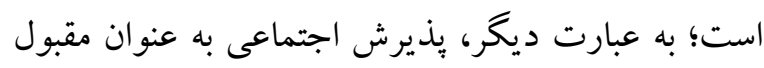
و مورد يذيرش بودن فرد از سوى خانواده، اطرافيان، دوستان و همسالان تعريف شده است (فريرا، آكويار،

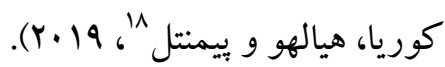
يذيرش اجتماعى باعث مىشود كه نوجوانان از ميان

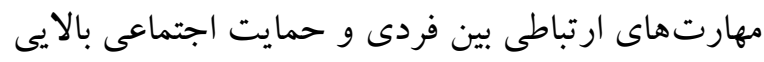
برخوردار شوند، به طورى كه مقبوليت و يذيرش آنان از سوى همسالان باعث دريافت حمايتهاى اجتماعى لازم

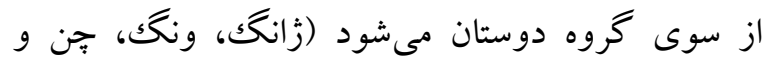

${ }^{12}$ - Nurahman, Isnaeni \& Ellianawati

13 - Emotional intelligence

14- Tiwari \& Bhat

15- Social acceptance

${ }^{16}$ - Rieffe, Ketelaar \& Wiefferink

${ }^{17}$ - Pascual-Sagastizabal

${ }^{18}$ - Ferreira, Aguiar, Correia, Fialho \& Pimentel
نوجوانى دورهاى با شروع و طول مدت متغير، بين كودكى و بزركسالى است كه از جمله مشكلات آنها مىتوان به مشكلات جنسى (اگبى، اوگوستينا، ايتيتا و

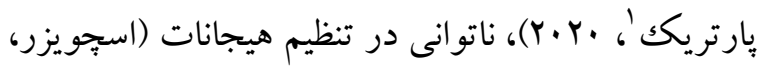

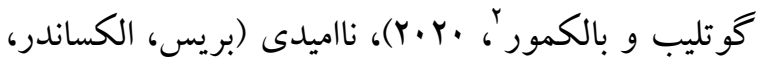
فراسر و فابس r' .Y.Y.Y)، ناتوانى در دوست يابى (بنر، هائو

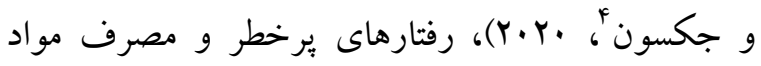

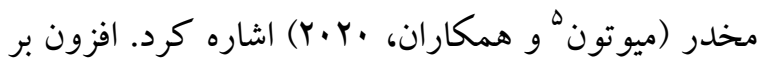
جنين مشكلاتى، يكى ديخر از مشكلات نوجوانان در اين سنين ويايين بودن سطح همدلى در نوجوانان دختر است

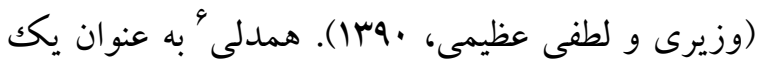

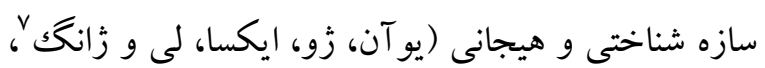

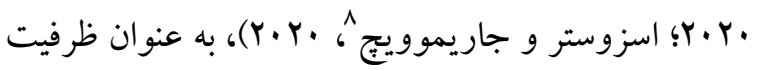
افراد براى ادراكك و فهم رفتار ديخران، تجربه هيجانات و احساسات آنها و بيان آنجه كه درك كردهايم توصيف شده است كه بعد شناختى آن به توانايى دركى ديدكاههاى طرف مقابل اشاره دارد (تارانتينو، دس دى

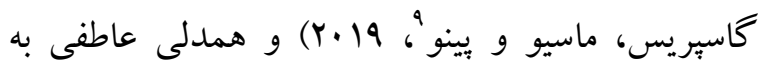
واكنشهاى عاطفى فرد است (مارتيناك دورسيس، اسموجور-آزيك،، رونسويكك-زوبكوويك و كوليكوهووس "' 19 (Y). همدلى نقش مهمى در بهبود مهارت هاى ارتباطى " افراد ايفا مى كند (نوراهمن، ايسناينى و

\footnotetext{
1- Egbe, Augustina, Itita, Patrick \& Bassey

2. Schweizer, Gotlib \& Blakemore

3 - Bryce, Alexander, Fraser \& Fabes

4 - Benner, Hou \& Jackson

5 - Mewton

6- Empathy

7. Yang, Zhu, Xia, Li \& Zhang

${ }^{8}$ - Szuster \& Jarymowicz

9- Tarantino, De Gasperis, Mascio \& Pino

${ }^{10}$ - Martinac Dorčić, Smojver-Ažić, Rončević Zubković \& KolićVehovec

${ }^{11}$ - Communication skills
} 
كمك كند. يكى از رواندرمانىهاى متكى بر روانكاوى، روان درمانى مبتنى بر آموزههاى لاكانى است كه در ايران يُوهش در مورد آن انجام نشده است. با توجه به اهميت همدلى، بذيرش اجتماعى و كفايت اجتماعى در نوجوانان به كارگيرى مداخلات روانشناختى مى تواند به به به بهبود مشكلات نوجوانان در اين زمينه كمكك كند. در ييشينه يزوهش مداخلاتى هماند معنا درمانى بر كفايت

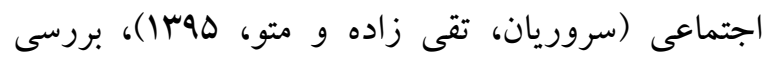
نقش همدلى در رشد كفايت اجتماعى (هيرن، توماس و

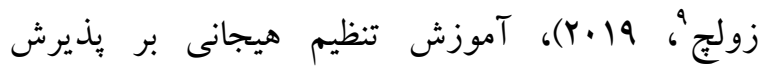
اجتماعى و همللى (خوش روش، خسروجاويد و حسين

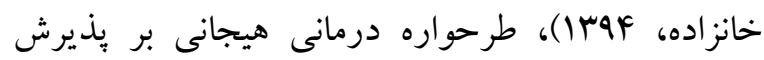
اجتماعى (تاشكه، دوازده امامى، بازانى، شاه حسينى و و مصطفى لو، IYYVII)، آموزش حل مسئله اجتماعى بر مؤلفه هاى كفايت اجتماعى (بيرامى، هاشمى نصرت آباد،

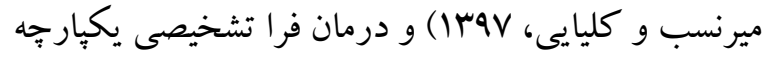
بر نظم جويى شناختى هيجان و همدلى (عثمانى و شكرى،

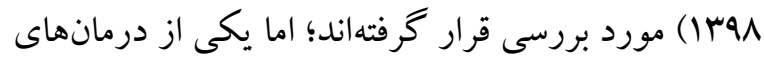
كه بر روى متغيرهاى مورد نظر در نوجو انان مورد بررسى .

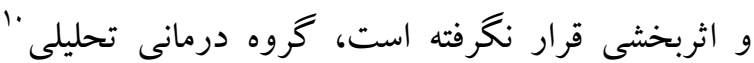

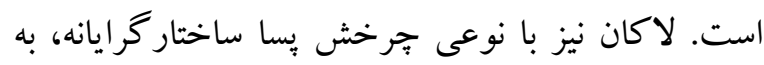

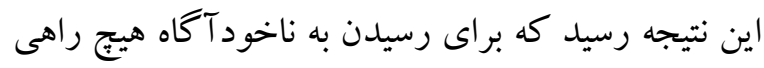
وجود ندارد؛ جز از طريق ايجاد و برقرار ساختن بستر "گفتمان) بين روانكاو و بيمار. كار لاكانى به طرزى عميقاً بحثانكيز روانكاوى را هم در مقام نظريه ذهن ناخود آكاه و هم در مقام فعاليتى بالينى دگر گون كرده

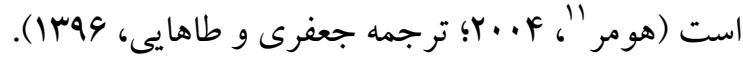

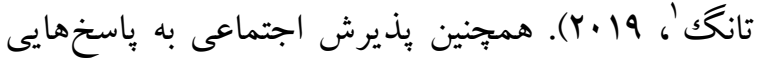
اشاره دارد كه افراد دوست دارند بر اساس هنجارهاى فرهنگى، در اجتماع مورد يسند واقع شده و مطلوبيت اجتماعى كسب كنند (ساربسكو، كاستى و روسو لَّ r.|r). به طورى كه مشكل در ارتباط اجتماعى و حل مسائل اجتماعى مىتواند موجب بروز مشكلاتى در يذيرش اجتماعى گردد. يذّيرش اجتماعى شامل اعتماد

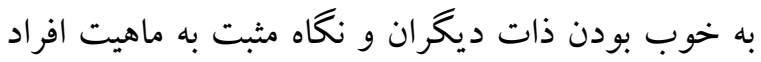

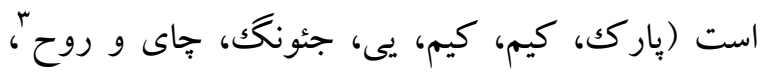

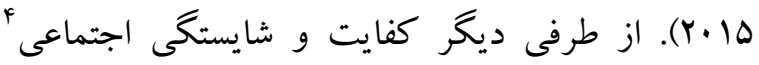
نقش مهمى در زندكى اجتماعى و فردى افر اد ايفا مى كند (فرناندس هو همكاران، 19 1Y). كفايت اجتماعى، با بهبود

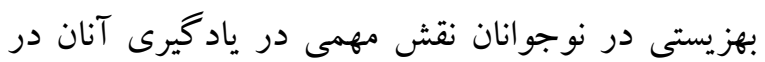
محيط مدرسه نيز دارد (زاجريسون، جانسون و لامرّك (Y.19). نوجوانانى كه از كفايت اجتماعى كمترى برخوردار هستند، مشكلات رفتارى بيشترى در زندگى اجتماعى و در محيط مدرسه در تعامل با همسالان خود

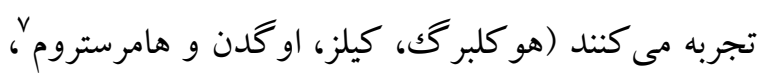
19.19). وقتى دانش آموزان از كفايت اجتماعى سطح بالايى نسبت به ديكران برخوردار نباشند در محيط مدرسه نياز با معلمان خود مشكلات تحصيلى و ارتباطى بيشترى از خود بروز مىدهند (بيلر سيهان و همكاران، 19 ب. (Y). با توجه به اهميت همدلى، يذيرش اجتماعى و كفايت

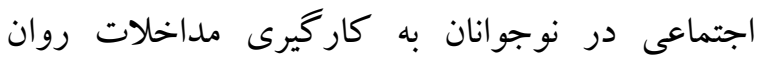
درمانى مى تواند به بهبود مشكلات نوجوانان در اين زمينه

\footnotetext{
1- Zhang, Wong, Chen \& Tang

2- Sarbescu, Costea \& Rusu

3. Park, Kim, Kim, Yi, Jeong, Chae \& Roh

4- Social competence

5 - Fernandes

${ }^{6}$ - Zachrisson, Janson \& Lamer

${ }^{7}$ - Hukkelberg, Keles, Ogden \& Hammerstrøm

8 - Bilir Seyhan
} 
مناطق Y Y كانه شهر تهران منطقه r و از آن منطقه به صورت تصادفى ساده دو مدرسه انتخاب و سيس يرسشنامهاى يُزوهش بر روى دانش آموزان آن مدارس

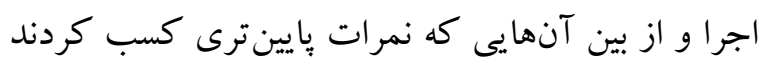
تعداد ·r نفر انتخاب شدند. بعل از اين مرحله با استفاده از روش نمونه گيرى تصادفى تعداد ·r نفر مورد نظر در دو

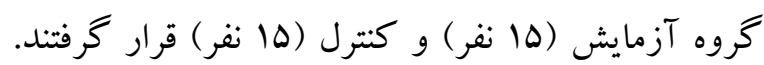

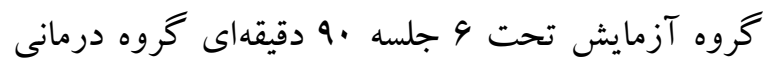
تحليلى لاكانى قرار گرفتند؛ در اين مدت گروه كنترل در ليست انتار گروه درمانى قرار داشتند. جلسات درمانى

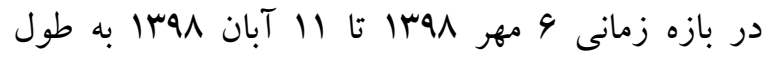
انجاميد كه در مجموع 9 جلسه آموزش داده شد. بعد از اتمام جلسات درمانى از هر دو گرووه در شرايط يكسان

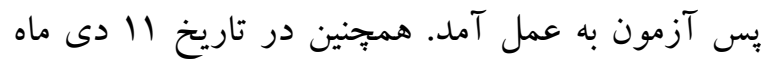
افراد هر دو گروه به همان برسشنامههاى كه در بيش آنه آزمون و پِس آزمون پِاسخ داده بودند، اين بار به سؤالات

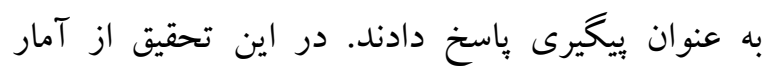
توصيفى (ميانكين و انحراف معيار) و آمار استنباطى لـى (تحليل واريانس با اندازه گيرى مكرر) آزمون استفاده شد. همجنين قبل اجراى تحليل مفروضههاى آن شامل آزمون

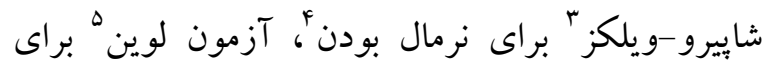

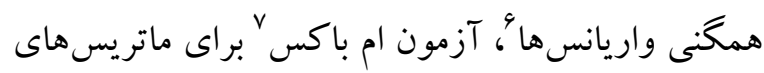

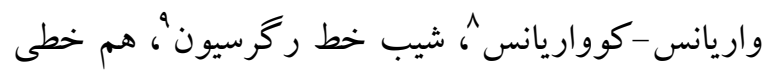
جند كانه "، كرويت موجلى استفاده شد. نرم افزار تحليل دادهها برنامه SPSS نسخه YF بود.

${ }^{3}$ - Shapiro-wilk

4 - Normality

5 - Levene's test

6 - Homogeneity of variance

7- Box M

${ }^{8}$ - Matrix variance covariance

9 - Homogeneity of regression

${ }^{10}$ - Multicollinearity
در مورد مكانيسم عمل درمان لاكانى و اينكه ضرورت و تناسب انتخاب اين درمان براى اين جامعه هدف يعنى دختران نوجوانان مىتوان كفت كه رواندرمانكر لاكانى به دنبال بهبود ادراكك خويشتن، توانايى عزت نفس، بهبود رابطه با ديخران است كه اين عوامل مى تواند نقش مهمى در بهبود همدلى، يذيرش و كفايت اجتماعى نوجوانان دختر دارد. به طورى كه بر اساس نتايج تحقيقات عزتنفس و بهبود رابطه با ديخر ان نقش مهمى در توانايى

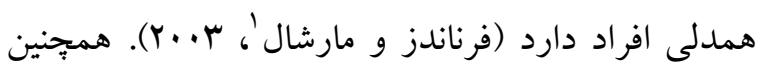
روان درمانى لاكانى منجر به بهبود شيوههاى منحصر به فرد ساز گارى و بهبود ديخر كاركردهاى ايخو در افراد

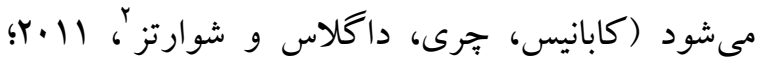

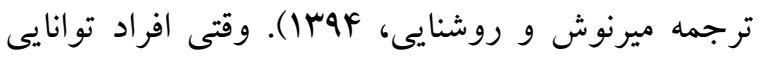
ساز گارى بالايى داشته باشند مىتواند در روابط با ديخران بذيرش و كفايت اجتماعى بيشترى را تجربه كنند؛ لذا درمان لاكانى مى تواند در اين يُوهش كار آمد باشد. با توجه به آنجه كفته شد در اين بثزوهش به بررسى اين

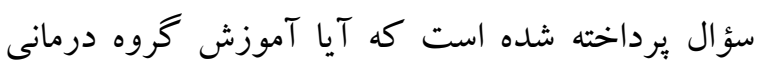
تحليلى لاكانى بر همدلى، يذيرش اجتماعى و كفايت

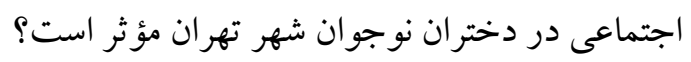

روش يزوهش حاضر از نظر هدف كاربردى و از نظر روش يُزوهش نيمه آزمايشى با طرح بيش آزمون و يس آزمون

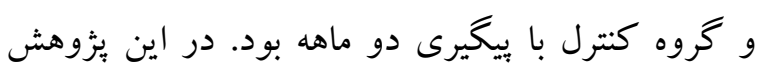
جامعه آمارى كليه نوجوانان دختر مدارس دولتى دوره اول و دوم متوسطه شهر تهران در سال 99-91"ا بودند. به صورت نمونه گيرى خوشهاى جند مرحلهاى ابتدا از بين

\footnotetext{
1. Fernandez \& Marshall

${ }^{2}$ - Cabaniss, Cherry, Douglas \& Schwartz
} 


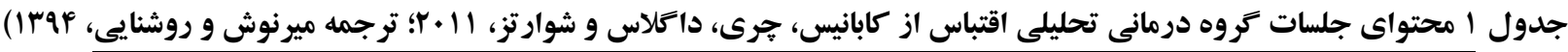 \\ محتواى جلسات}

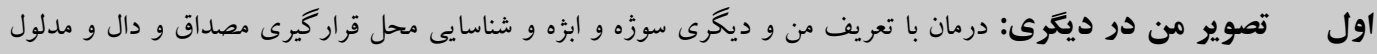

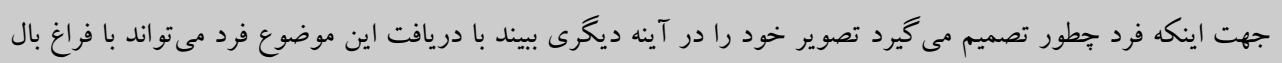
بيشتر به مبحث همدلى ببردازد.

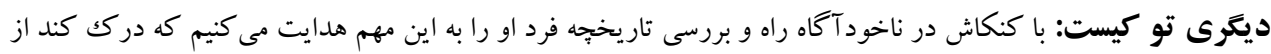

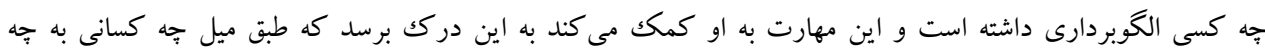

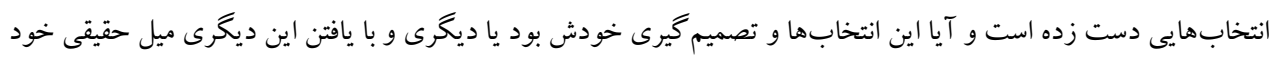

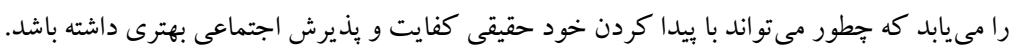

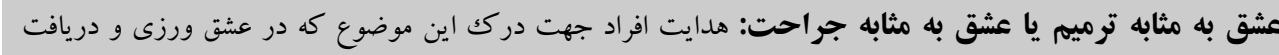

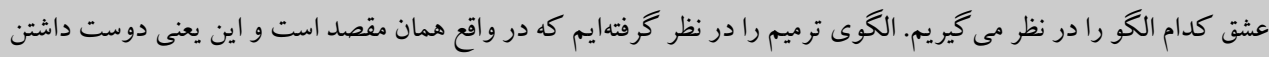

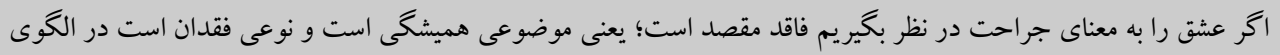

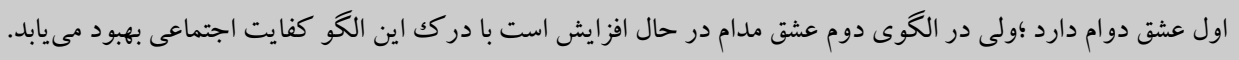

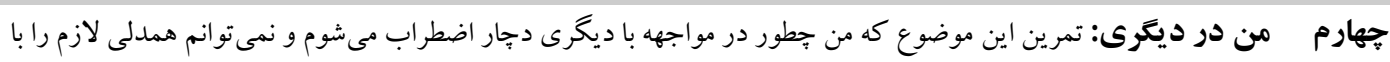

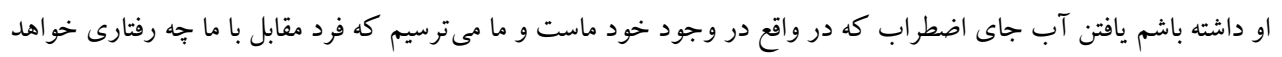

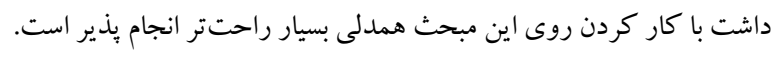

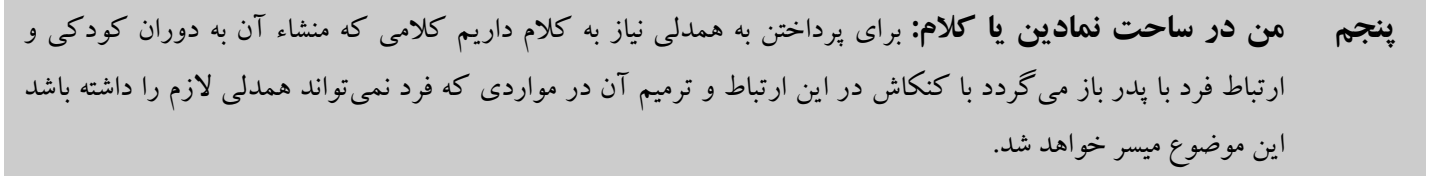

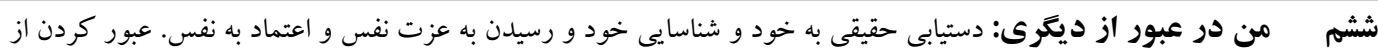

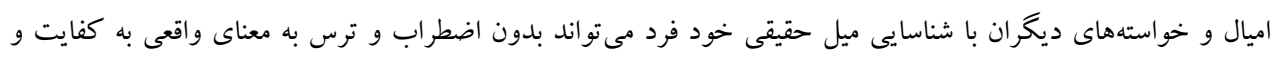

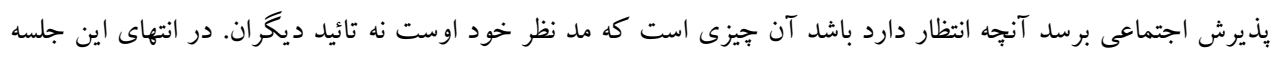

$$
\text { بس آزمون اجرا شد. }
$$

كرونباخ بُعد عاطفى AV/ • و شناختى A9/ • (خانجانى و بهادرى خسروشاهى، 9911) و ضريب (9/، • به دست آمده است (كاجى اصفهانى، عارفى، آقايى جشوقانى، اصلى آزاد و فرهادى، وهM1). در خارج از كشور نيز

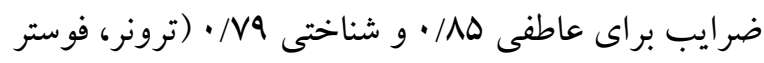

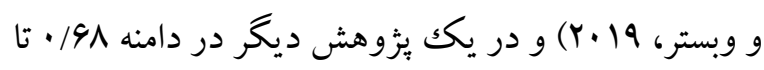

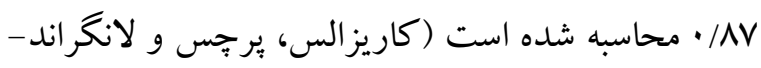

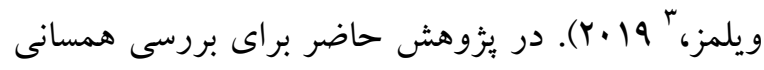
درونى مقياس از آلفاى كرونباخ استفاده شده است كه ضريب آلفاى كرونباخ Ar/ • به دست آمده است.

\footnotetext{
3. Carrizales, Perchec \& Lannegrand-Willems
}

سوم 
ييلاق، حاجى يخجالى و مهر ابى زاده هنرمند،

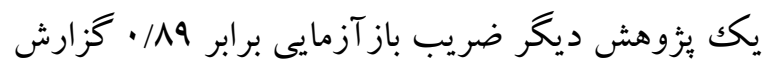
شده است (شريعتمدار و بيورگراوند، سهبا). روايى محتوايى مقياس مورد تائيد قرار گرفته است و ضريب همبستخى بين متخصصين MA/ • ذكر شده است (صليبى و مدرسى، ه9ب1). در خارج كشور بايايى درونى مقياس بر اساس روش آلفاى كرونباخ براى مؤلفههاى مقياس در دامنه بين VD/· تا /N/ • كزارش شده است (يترانوويج،

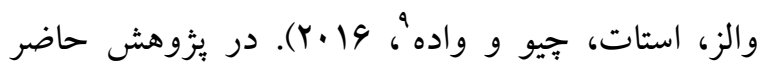
براى بررسى همسانى درونى مقياس از آلفاى كرونباخ

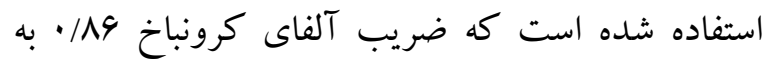
دست آمله است.

يافته ها

براساس نتايج، سن در گروه آزمايش 9 نفر (•F درصد)

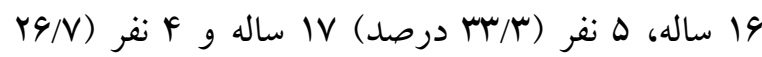

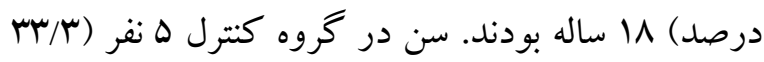

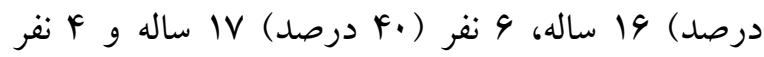

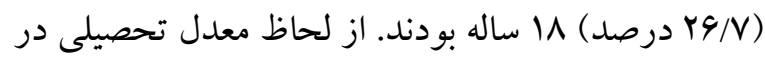

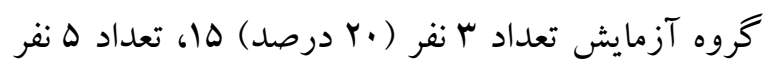

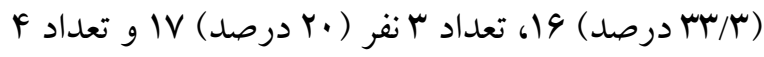
نفر (Y/V درصد) \\ بود. از لحاظ معدل تحصيلى در

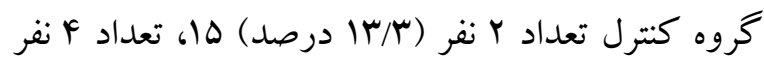

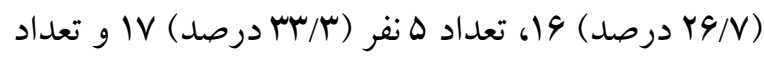

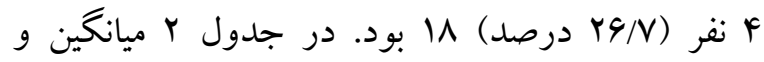
انحراف معيار متغيرهاى يزٔوهش گروه آزمايش و كنترل در بيش آزمون، بـ آزمون و بيگيرى آمده است.

\footnotetext{
${ }^{9}$ - Petranovich, Walz, Staat, Chiu \& Wade
}

مقياس يذي يرش اجتماعى' (SDS) كراون-مارلو' (.99 1):

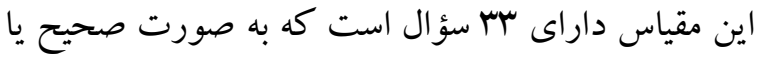
غلط ياسخ داده مىشود (كينگگ، دونكان، كلينكنبئارد،

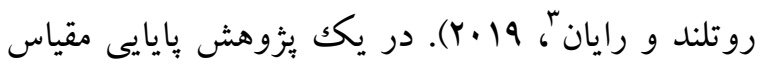
با آلفاى كرونباخ بررسى و ضريب 194/ به دست آمده است (عظيمى، شريعتمدار و نعيمى، واگرى مقياس بررسى و ضريب همبستخى با مقياس

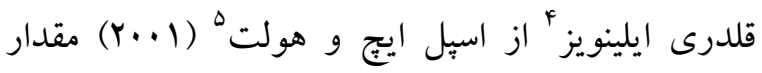

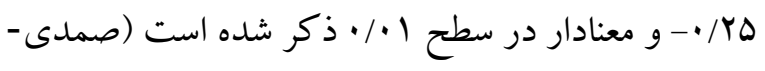
فر و نريمانى، وهب1). در خارج از كشور در يك ئزوهش براى بررسى يايايى مقياس از روش آلفاى كرونباخ استفاده شده است كه ضريب VY/ • به دست آمده است

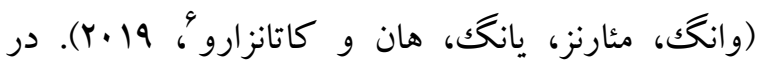
ئزوهش حاضر براى بررسى همسانى درونى مقياس از آلفاى كرونباخ استفاده شده است كه ضريب آلفاى كرونباخ V9/ • به دست آمده است.

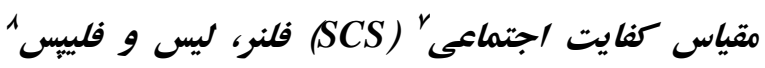

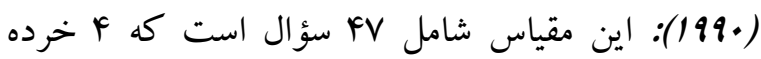
مقياس كفايت شناختى، رفتارى، هيجانى و آمايههاى

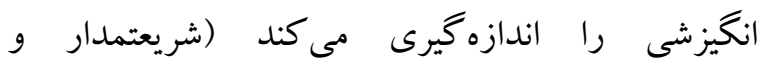
بور گر اوند، سوس ا). نمره گذارى مقياس در طيف ليكرت

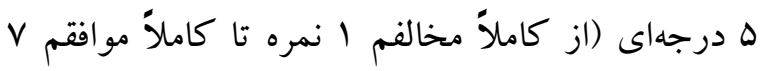

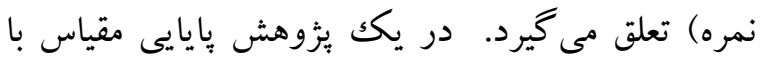
آلفاى كرونباخ بررسى و ضريب VV/ • به دست آمده

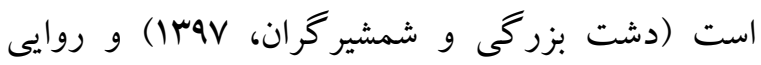
عاملى در دانشآموزان متوسطه است (علامه، شهنى

\footnotetext{
1- Social Desirability Scale (SDS)

${ }^{2}$ - Marlowe- Crowne

3 - King, Duncan, Clinkenbeard, Rutland \& Ryan

4- Illinois

5 - Espelage \& Holt

6 - Wang, Mearns, Yang, Han \& Catanzaro

7- Social Competence Scale (SCS)

${ }^{8}$ - Felner, Lease \& Phillips
} 


\begin{tabular}{|c|c|c|c|c|c|}
\hline \multicolumn{2}{|c|}{ انحراف معيار } & \multicolumn{2}{|c|}{ ميانگين } & \multirow[t]{2}{*}{ مرحله } & \multirow[t]{2}{*}{ متغير هاى بذوهش } \\
\hline كنترل & آزمايش & كنترل & آزمايش & & \\
\hline$\cdot / 941$ & ·/AMF & $r r / \Lambda$. & $r F / I T$ & ي يِش آزمون & \multirow[t]{3}{*}{ همدلى عاطفى } \\
\hline$\cdot$ /AMF & $1 / \cdots$ & $r r / q r$ & $r \Delta / \cdot$ & يس آزمون & \\
\hline$\cdot$ /AMF & $\cdot / 991$ & $r r / q r$ & TF/QT & بيخيرى & \\
\hline$\cdot / A \Lambda F$ & $.191 \mathrm{~V}$ & $r \cdot / v$ & $r \cdot 19 \mathrm{~V}$ & ي يش آزمون & \multirow[t]{3}{*}{ همدلى شناختى } \\
\hline.$/ 910$ & $1 / 911$ & $r \cdot / \wedge V$ & Tr/YV & يس آزمون & \\
\hline - /AGY & $r / \cdots V$ & $r \cdot / \Lambda \cdot$ & $r Y / r$ & بيخيرى & \\
\hline$\cdot / V \Delta 9$ & $\cdot / v \cdot r$ & $\mathrm{~V} / \cdot \cdot$ & $\mathrm{V} / \cdot \mathrm{V}$ & ي بيش آزمون & \multirow[t]{3}{*}{ يذيرش اجتماعى } \\
\hline$\cdot / V V \Delta$ &.$/ 910$ & $V / r$. & N/Ir & يس آزمون & \\
\hline$\cdot / V V \Delta$ & $\cdot / 991$ & $V / r$. & $\Lambda / \cdot V$ & ييخيرى & \\
\hline$\cdot N \cdot F$ & . MAF & $1 \cdot / v r$ & $1 \cdot / \wedge V$ & ي بيش آزمون & \multirow[t]{3}{*}{ كفايت شناختى } \\
\hline$\cdot / \vee 99$ & ./AMF & $1 \cdot / 94$ & $\mid r / \Delta r$ & يس آزمون & \\
\hline$\cdot / \vee 99$ & - /AMF & $1 \cdot / 9 r$ & $\mid r / F V$ & بيخيرى & \\
\hline $1 / Y 91$ & I/VDI & $\Delta r / 9$ & $\Delta r / Y V$ & ي بيش آزمون & \multirow[t]{3}{*}{ كفايت رفتارى } \\
\hline I/rAV & $1 / \Delta 9 \Delta$ & $\Delta r / V r$ & $\Delta \Delta / 9$ & يس آزمون & \\
\hline $1 / r 9 V$ & l/GFY & $\Delta r / 9 V$ & $\Delta \Delta / \Delta r$ & بيخيرى & \\
\hline$\cdot / A F \Delta$ &.$/ \mathrm{Vaq}$ & $11 / \cdots$ & $1 \cdot / 94$ & بيش آزمون & \multirow[t]{3}{*}{ كفايت هيجانى } \\
\hline . /Arr & $1 / 194$ & $11 / 1 r$ & $\mid r / \cdot V$ & يس آزمون & \\
\hline - /AMF &.$/ M r F$ & $11 / 1 r$ & $\mid r / \cdot$. & ييخيرى & \\
\hline - /AFD & $\cdot / 991$ & $\mid r / \cdot$ & $\mid r / \cdot V$ & بيش آزمون & \multirow[t]{3}{*}{ آمايههاى انتيزشى } \\
\hline.$/ 910$ & . IVYF & $1 r / 1 r$ & $10 / 9$ & يس آزمون & \\
\hline.$/ 910$ & $1 / 9 \wedge \Delta$ & & lo/or & ييخيرى & \\
\hline
\end{tabular}

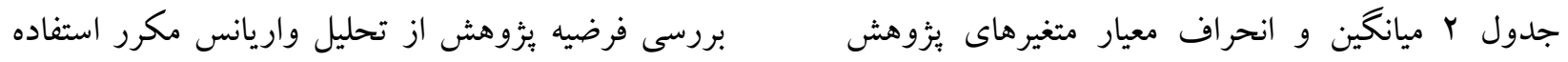

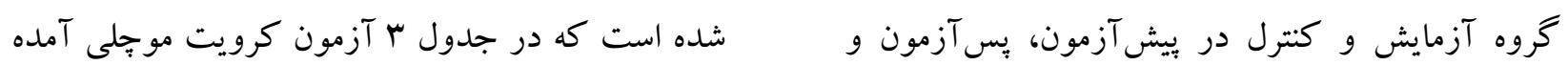
بيخيرى متغيرهاى بُزوهش را نشان مىدهد. در ادامه به است.

\begin{tabular}{|c|c|c|c|c|}
\hline معنى دارى & درجه آزادى & آمارهى كاى دو & كرويت موجلى & متغير هاى يخوهش \\
\hline.$/ \cdots 1$ & r & rV/TrD & $\cdot / Y \Delta I$ & همدلى عاطفى \\
\hline$\cdot / \cdots 1$ & r & $\Delta \Lambda / \mu q$. &.$/ 110$ & همدلى شناختى \\
\hline$\cdot / \cdots 1$ & r & $F q / M T \mid$ &.$/ 191$ & يذيرش اجتماعى \\
\hline$\cdot / \cdots 1$ & r & $\Delta r / 949$ &.$/ \mathrm{Fr}$ & كفايت شناختى \\
\hline$\cdot 1 \cdot \cdot 1$ & r & $\mathrm{Vq} / \cdot \mathrm{VA}$ & .1 .9 & كفايت رفتارى \\
\hline$\cdot / \cdot \cdot 1$ & r & $\Delta \Delta / F \Delta 1$ & $\cdot / 1 Y A$ & كفايت هيجانى \\
\hline
\end{tabular}


تخطى از الكوى آمارى F صورت گرفته است. در نتيجه از آزمونهاى جايگزين محافظه كارانه گرين هاوس ارسئ كيرز براى بررسى اثرات درون آزمودنى درمان استفاده شد كه نتايج در جدول F آمده است.
براساس جدول ץ آزمون كرويت موجلى مقدار سطح

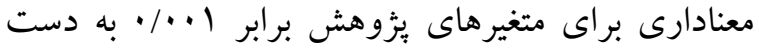
آمده است؛ لذا فرض كرويت رد مىشود. در نتيجه از فرض يكسان بودن واريانسها و به گونهاى دقيقتر شرط همگنى ماتريس كواريانس اطمينان حاصل نشد ؛ لذا بـأ

جدول f نتايج تحليل واريانس اندازهكيرى مكرر متغيرهاى ثئوهش در سه مرحله اجرا

\begin{tabular}{|c|c|c|c|c|c|}
\hline توان آمارى & ضريب تأثير & معنى دارى & Tاره F & منابع تغيير & متغيرهاى يخوهش \\
\hline . /994 & $\cdot / f \cdot V$ & $\cdot / \cdot \cdot 1$ & 19/1Ar & عامل & \multirow{3}{*}{ همدلى عاطفى } \\
\hline $.19 \mathrm{VA}$ & . /NAr &.$/ .11$ & $9 / 491$ & كروه & \\
\hline.$/ 911$ &.$/ 190$ & $\% r$ & 1.1 .91 & عامل & \\
\hline.$/ 9 T V$ & $\cdot / r \cdot \lambda$ &.$/ .1$ & $\mid r / 4 \wedge q$ & عامل & \multirow{3}{*}{ همدلى شناختى } \\
\hline . $/ \Delta \mathrm{rA}^{\prime}$ &.$/ 149$ &.$/ \% \Delta$ & $F / F 10$ & 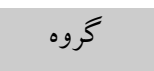 & \\
\hline$\cdot / 9 \vee 9$ & $\cdot /$ TOG & $\cdot / \cdot 1$ & Q/9५0 & عامل گگروه & \\
\hline ./994 & . / RIr &.$/ \cdot 1$ & $19 / 9 \ldots$ & 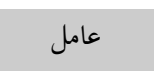 & \multirow{3}{*}{ بذيرش اجتماعى } \\
\hline$\cdot 19 \cdot 1$ &.$/ 191$ & 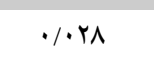 & $\Delta / r \Delta q$ & كروه & \\
\hline - /AFV & . MFT &.$/ \cdot 1$ & N/qVI & عامل گرموه & \\
\hline$\cdot / 999$ & . $/ \Delta 94$ &.$/ \cdot 1$ & F.NGG & 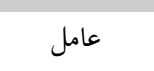 & \multirow{3}{*}{ كفايت شناختى } \\
\hline$\cdot / 919$ & $\cdot / r q v$ &.$/ \cdot 1$ & $11 / 499$ & 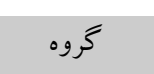 & \\
\hline.$/ 999$ & $\cdot / F V I$ &.$/ \cdot 1$ & $r F / Q T 1$ & عامل گ گروه & \\
\hline$\cdot / 9 \Delta V$ & $\cdot /$ /TYG & $\cdot / \cdot 1$ & $\cdot / 198$ & عامل & \multirow[t]{3}{*}{ كفايت رفتارى } \\
\hline ./994 & - / FYV & $\cdot / \cdot 1$ & $r \cdot / \wedge 9 \wedge$ & كروه & \\
\hline$\cdot / 9 Y 1$ & $\cdot / 91$ & $\% r$ & $11 / q \cdot r$ & عامل & \\
\hline.$/ 910$ & . r M &.$/ \cdot 1$ & $I V / r V T$ & 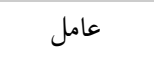 & \multirow[t]{3}{*}{ كفايت هيجانى } \\
\hline . & $\cdot / 1 \cdot v$ &.$/ \% A$ & $F / M r q$ & كروه & \\
\hline ./NQV & $\cdot /$ TVD &.$/ .1$ & $1 . / 949$ & عامل كروه & \\
\hline.$/ 999$ & . $/ \Delta T^{\prime}$ &.$/ .1$ & MINIA & عامل & \multirow[t]{3}{*}{ آمايه هاى انكيزشى } \\
\hline$\cdot / 911$ & $\cdot /$ rAS &.$/ \cdot 1$ & IV/DFT & 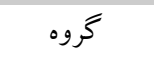 & \\
\hline.$/ 999$ & $\cdot / F V A$ &.$/ . \cdot 1$ & TQ/GTr & عامل * گروه & \\
\hline
\end{tabular}


ايجاد كرده است. در ادامه براى مقايسه دو به دوى ميانگين تعديل مراحل آزمون (ييش آزمون، يس آزمون و ييخيرى) در متغيرهاى وابسته در جدول ها آمده است.
نتايج جدول f نشان مىدهد كه گروه درمانى تحليلى لاكانى تفاوت معنادارى را در سه مرحله اندازهگيرى در نمرات همدلى، يذيرش و كفايت اجتماعى سه گروه

\begin{tabular}{|c|c|c|c|c|c|}
\hline معنى دارى & تفاوت ميانكين & آزمونها & \multicolumn{2}{|c|}{ ميانكين تعديل شده } & متغيرهاى بثزوهش \\
\hline.$/ \cdot 1$ & $-\cdot / 0 \ldots *$ & بِيش آزمون-ِس آزمون & $r r / q V$ & يِش آزمون & \multirow{3}{*}{ همدلى عاطفى } \\
\hline$\cdot / \cdot 1$ & $-\cdot / 4 q \mathrm{~V}^{*}$ & بيش آزمون-بيكيرى & $Y F / F V$ & يس آزمون & \\
\hline$\cdot / 9 \vee \wedge$ & 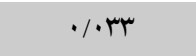 & بِ آزمون-بيخيرى & TF/FT & بي ي يخيرى & \\
\hline$\cdot / \cdot r$ & $-\cdot / \Lambda 9 V^{*}$ & يِش آزمون-بِ آزمون & $r \cdot / v \cdot$ & يشي آزمون & \multirow{3}{*}{ همدلى شناختى } \\
\hline $1 / .49$ & $-\cdot / A \cdot \cdot$ & بيش آزمون-بيكيرى & $r Y / \Delta V$ & ي ع آزمون & \\
\hline$\cdot 10 \cdot 0$ & $.1 .9 \mathrm{~V}$ & پِ آزمون-يِيخيرى & $r / / \Delta$. & بيخيرى & \\
\hline.$/ \cdot 1$ & $-.19 \pi T^{*}$ & يُيش آزمون-ِس آزمون & $V / \cdot r$ & بيش آزمون & \multirow[t]{3}{*}{ يذيرش اجتماعى } \\
\hline.$/ \cdot 1$ & $-\cdot / 9 \cdot \cdot^{*}$ & يِيش آزمون-بيكيرى & $r / 9 \mathrm{~V}$ & بس آزمون & \\
\hline.$/ 9 \vee \wedge$ &. & ي" آزمون-يِيكيرى & V/qT & بي بيخيرى & \\
\hline$\% \cdot \cdot 1$ & $-\cdot / 9 \pi r^{*}$ & بيش آزمون-بِ آزمون & $1 \cdot / 1$ & بيش آزمون & \multirow{3}{*}{ كفايت شناختى } \\
\hline.$/ \cdots 1$ & $-\cdot / 9 . *^{*}$ & يِيش آزمون-بيخيرى & $11 / N r$ & بـ آزمون & \\
\hline.$/ 9 \vee 9$ &.$/ 4 r$ & 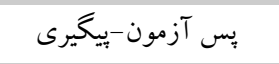 & $11 / v$ & 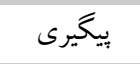 & \\
\hline.$/ .1$ & 1/rTr" & بِيش آزمون-بس آزمون & $\Delta r / a r$ & ي بيش آزمون & \multirow[t]{3}{*}{ كفايت رفتارى } \\
\hline$\cdot \cdot \cdot r$ & $1 / 19 V^{*}$ & بيش آزمون-بيكيرى & $\Delta F / I V$ & بس آزمون & \\
\hline$\cdot 10 \cdot 0$ & $-.1 .9 \mathrm{~V}$ & يّ آزمون-يِيكيرى & $\Delta F / l$. & بي بيخيرى & \\
\hline$\cdot / \cdot 1$ & $-\cdot / 9 \pi \mu^{*}$ & يِش آزمون-سِس آزمون & $1 . / 91$ & ي بيش آزمون & \multirow[t]{3}{*}{ كفايت هيجانى } \\
\hline.$/ .1$ & $-.19 \cdot *^{*}$ & يِيش آزمون-بيخيرى & $11 / 9$ & قِس آزمون & \\
\hline.$/ 9 \vee \wedge$ &.$/ . r r$ & يس آزمون-يِيخيرى & $11 / \Delta V$ & بي بيخيرى & \\
\hline.$\cdot .1$ & $-1 / \pi T r^{*}$ & يِيش آزمون-سِ آزمون & $\mid r / . r$ & بيش آزمون & \multirow[t]{3}{*}{ آمايههاى انكيزشى } \\
\hline$\cdot \cdots 1$ & $-1 / r \ldots *$ & بيش آزمون-بيكيرى & $\mid F / T V$ & يس آزمون & \\
\hline.$/ 9 \vee 9$ &.$- / . \mu F$ & بِ آزمون-بيكيرى & $1 F / T r$ & بي بيخيرى & \\
\hline
\end{tabular}

يشيش آزمون با بس آزمون) و (تفاوت ميانگين بيش آزمون با بيخيرى" بيشتر و معنادارتر از (اتفاوت ميانگين "بس آزمون و بيگيرى" است كه اين نشان دهنده آن است كه گرووه درمانى تحليلى لاكانى بر همدلى، يذيرش و و كفايت اجتماعى در مرحله بس آزمون تأثير داشته است و تداوم اين تأثير در مرحله بيگيرى رادر برداشته است.
به منظور مشخص نمودن اينكه همدلى، بذيرش و كفايت اجتماعى در كدام مرحله با هم تفاوت معنىدارى دارند از آزمون تعقيبى بن فرونى استفاده شد كه به مقايسه دو به دو ميانگين ها يرداخته شده است. جدول ها نشان مىدهد

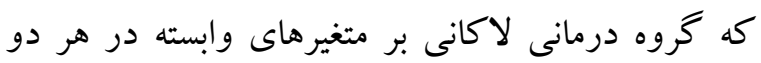
مرحله بِ آزمون و بيگيرى تأثير معنىدارى داشته است.

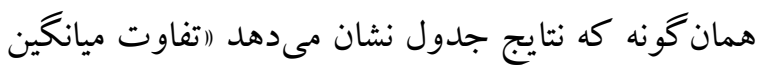


همدلى بالاتر ميزان بخشودگى و مهربانى بيشترى در

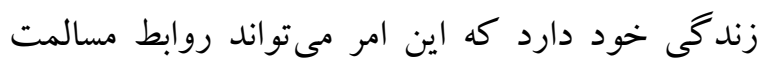
آميز و مهرورزانهاى در قبال ديخران را براى آنان به

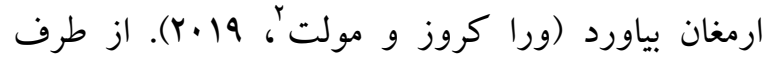
ديكر ابزه يكك وازه تكنيكى در نوشتهاى روانكاوى فرويد است و بيشتر از اشاره به يكك موضوع غير انسانى، به به به شخص يا عملى اشاره دارد كه ميل فرد در آن جهت

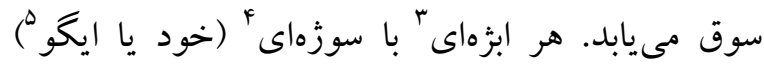

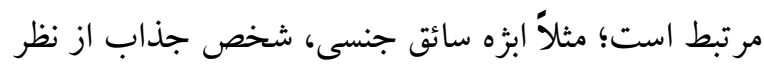
جنسى (سوزه) است. يكى از تحولات روانكاوى و

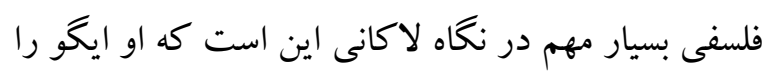
يكك ابزه مىدانست نه يكك سوزه. در واقع بين ايكو و

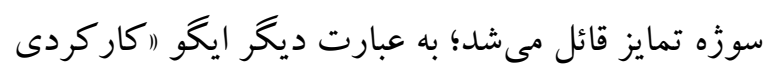

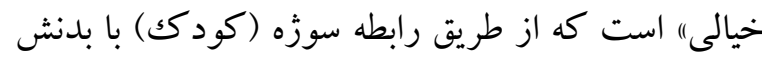
در مرحله آينهاى ايجاد مىشود. در واقع ايگو محصول همين رابطه است. در حالى كه براى شكل گيرى سوزه، رويدادهاى ديخرى نيز بايد وجود داشته باشد. اين تصور

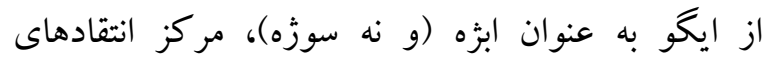
هميشكى لاكانى نسبت به روانشناسان ايخو امريكايى بود. لاكان با اين رويكرد روانشناسان ايخو آمريكايى مخالف بود كه فقط در يبى تقويت ايگوى بيماران خود بودند؛

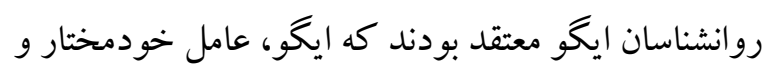
بلدون تعارض وجود انسان است. بر خلاف اين ديدگاه، لاكانى ايخو را ذاتا نوروتيك مىداند. بر اين اساس وقتى لهى شخصيت فرد در گير اختلال نباشد بهتر با خود و ديكران همدلى مى كند؛ لذا منطقى است كه گروه درمانى تحليلى

$$
\text { بر همدلى مؤثر باشد. }
$$

2. Vera Cruz \& Mullet

3 - Object

4- Subject

5- Igo
نتايج مؤيد آن بود كه بين گرووههاى آزمايش و كنترل از لحاظ يس آزمون همدلى، يذيرش اجتماعى و كفايت اجتماعى با كنترل بيش آزمون تفاوت معنادارى وجود دارد؛ بنابر اين فرضيه بُزوهش مبنى بر اينكه گروه درمانى تحليلى بر همدلى، بذيرش و كفايت اجتماعى در دختران نوجوان شهر تهران مؤثر است تائيد شد و درمان در طول زمان ماندكاراست؛ لذا همسويى و ناهمسويى نتيجه به دست آمده با نتايج تحقيقات قبلى مشخص نيست؛ اما اين نتيجه به دست آمده با مداخلات قبلى كه بر روى همدلى، يذيرش اجتماعى و كفايت اجتماعى انجام شده است همجون معنا درمانى بر كفايت اجتماعى (سروريان، تقى زاده و متو، ههب()، آموزش مهارتهاى اجتماعى بر كفايت اجتماعى (صديق كرج و اقدسى، وهبا))، آموزش تنظيم هيجانى بر يذيرش اجتماعى و همدلى (خوش روش، خسرو جاويد و حسين خانزاده، وqMا)، طرحواره درمانى هيجانى بر بِذيرش اجتماعى (تاشكه، دوازده

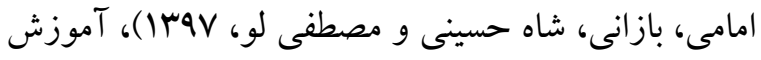
حل مسئله اجتماعى بر مؤلفهاى كفايت اجتماعى

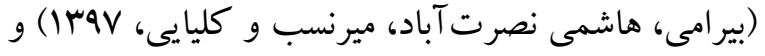
درمان فرا تشخيصى يكيارجه بر نظم جويى شناختى

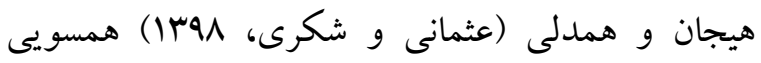
دارد. در تبيين تأثير گروه درمانى تحليلى بر همدلى مىتوان كفت يكى از اصول آموزش داده شده در جلسات گروه درمانى تحليلى لاكانى گوش دادن همدلانه است. همدلى مىتواند نقش مؤثرى در برقرارى روابط بين فردى افراد داشته باشد (كاميساسكا، ميراگولى،

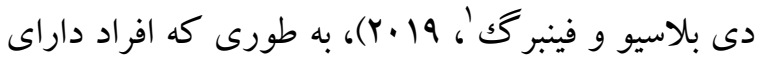

\footnotetext{
1. Camisasca, Miragoli, Di Blasio \& Feinberg
} 
يذيرش اجتماعى وى در نزد ديخران و همسالان او بيشتر

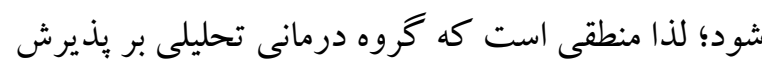
اجتماعى مؤثر باشد.

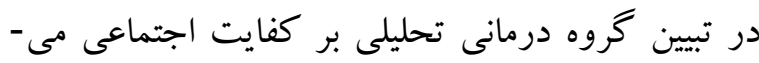
توان كفت كودكى با ديدن تصوير خود در مرحله آينهاى، خودش را به صورت يكِّارجه و معنادار تصور مى كند. اين تجربهى آرامش بخش، براى او لذتبخش است. به عقيدهى لاكانى، نوزاد از طريق (اتشويقهاى

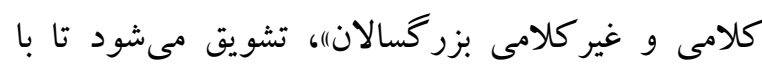
تصوير درون آينه، همانندسازى كند و آن راعنوان "امن ")

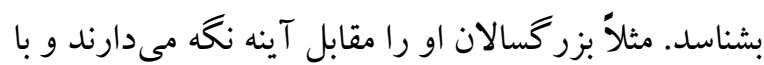
اشاره و لبخند به نوزاد مى گويند: اين تويى. در واقع، لاكانى ازخودبيگانكى را در برابر خود ذاتى ' قرار مىدهد. وقتى هسته تصورى ايكو با جيزهايى مانند تحريكك بيرونى، تشويقهاى كلامى و غير كلامى مراقبان اوليه، ايجاد شود، آن رادور شدن از خود واقعى مىداند. به اين معنا كه اين تصوير سرانجام جاى من كودكك را

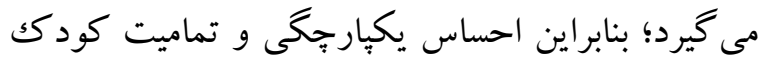
به بهاى ديخرى بودن اين خود، يعنى همان تصوير آينهاى، تمام مىشود. به عقيدهى لاكانى، انسانها كل زندگى خود را صرف تعقيب بيهودهى همان هماهنكى و هارمونى دست نيافتنى اوليهاى مى كنند كه تصوير آينه وعده آن را داده بود كه اين امر مىتواند كفايت اجتماعى كودكك را در سنين كودك و نوجوانى تحت تأثير منفى خود قرار دهد. در گروه درمانى تحليلى لاكانى، به فرد نوجوان آموزش داده مىشود كه تصورى كه از خودش داشته و توسط والدين اشباع شده را حذف و فرد نوجوان را كمكك كند تا با شناخت بيشتر خود كنار بيايد و بيشتر

${ }^{1}-\mathrm{Me}$

${ }^{2}$ - Ontological asserting ego
در تبيين گروه درمانى تحليلى بر يذيرش اجتماعى مى توان كفت لاكانى عقيده دارد كه نوزاد در بدو تولد، بدن خود را تكه تكه و اجزاى آن را جدا از هم احساس مى كند. به همين دليل به شدت به والدين خود نيازمند است. تجربهى داشتن بدنى جدا از هم و وابسته به ديخران، براى نوزاد خوشايند نيست و منشأ اضطراب، يريشانى و سرخوردگى اوست. اين درماندگى اوليه نوزاد، يعنى (ناتوانى حركتى و وابستخى به يرستارى") و همجين تجربهى عواطف همراه آن، محرك اصلى

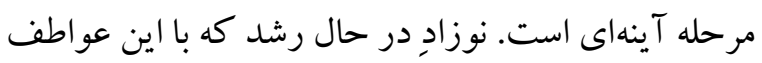
منفى برانگيخته مىشود، وقتى تصوير خود را در آينه مىييند، اميد يِيدا مى كند كه مىتواند بر ناتوانى اوليهى خود غلبه كند و خود را يكِارجه و كامل بييند. با اين حال در ابتدا هنوز خود را تكه تكه و جدا از هم احساس مى كند؛ اما تصوير آينه تسلط نوزاد بر بدنش را مهيا مى كند و در مقابل احساس تكه تكه بودن كودك، مىايستد. در نهايت نوزاد خود را با تصوير درون آينه يكى مىبيند و با آن همانند سازى مى كند. در صورتى كه نوجوان در دوران كودكى اين مرحلهاى آينهاى را به خوبى برطرف نكرده باشد همواره در طول دوره كودكى و نوجوانى با اضطراب و يريشانى و سرخوردگى همراه

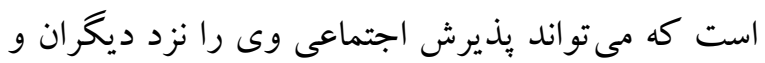

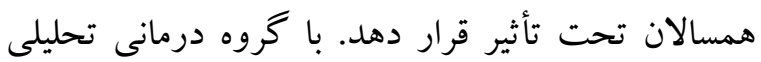
مبتنى بر روانكاوى لاكانى نوجوان ياد مى كيرد كه

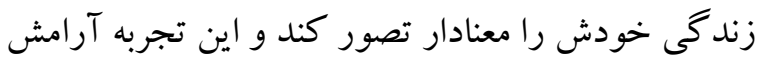
بخش براى او لذت بخش بوده و احساس آرامش و بهزيستى ناشى از آن مىتواند روابط اجتماعى وى را تحت تأثيرات مثبت خود قرار دهد و با همسالان خود روابط مثبت ترى را برقرار كند و همين امر سبب مىشود 
خود، درمان شفقت به خود و غيره مىتواند نتايج اثربخشى را بر بهبود همدلى، يذيرش اجتماعى و كفايت اجتماعى نوجوانان دختر در يى داشته باشد. به محققان علاقهمند در اين حوزه بيشنهاد مىشود به منظور بالا بردن اعتبار بيرونى از نمونههايى با حجم بيشتر و در گروههاى اجتماعى گوناگون استفاده كنند.

همجنين بيشنهاد مىشود، علاوه بر استفاده از ابزارهاى خود گزارش دهى كه امكان سو گيرى در آنها محتمل است بيشنهاد مىشود كه از روشهاى بزّوهشى ديخر مانند مصاحبه و مشاهده براى سنجش اين متغير استفاده

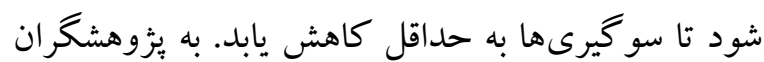
يشنهاد مىشود با تكرار اين بثوهش، با در نظر گرفتن

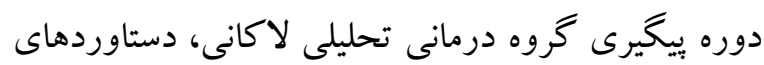
درمانى اين مداخلات را در طول زمان بر روى همدلى، يذيرش اجتماعى و كفايت اجتماعى نوجوانان دختر نيز مورد بررسى قرار گيرد. گرووه درمانى لاكانى بر همدلى دختران نوجوان اثربخش بود. بر اين اساس به روانشناسان،

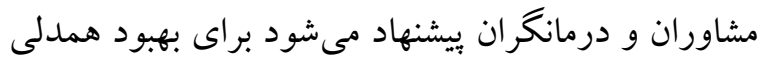
عاطفى و شناختى نوجوانان دختر با بر گزارى كار كاههاى روانشناختى گروه درمانى تحليلى لاكانى به نوجوانان دختر كمكك كنند تا در زمينه تقويت همدلى و مهربانى با خود و ديگر بهتر با مشكلات دوره نوجوانى كنار آيند؛ لذا مىتوان از گروه درمانى تحليلى لاكانى در مدارس دخترانه به عنوان درمانى راحت، در دسترس و كم هزينه براى بهبود مشكلات مانند عدم همدلى نوجوانان استفاده كرد. گروه درمانى تحليلى لاكانى بر يذيرش و كفايت اجتماعى دختران نوجوان اثربخش بود. يبشنهاد مىشود اين درمان را به عنوان يكك بسته درمانى كار آمد و كم كم هزينه، از سوى مراكزى كه با نوجوانان دختر در ارتباط
به خود واقعى خويش نزديك شود و از خودش بيكانه نباشد؛ بنابراين نوجوانى كه از خود بيگانه نباشد و خود واقعيش را بشناسد نسبت به توانمندىها و شايستكىهاى خود بيشتر واقف مىشود؛ لذا منطقى است كه گروه درمانى تحليلى بر كفايت اجتماعى مؤثر باشد. از آنجايى كه اين ئزوهش بر روى دختران نوجوان مشغول به تحصيل مدارس متوسطه شهر تهران صورت كرفته است، در تعميم نتايج اين بثوهش به دانش آموزان ساير شهرها به دليل تفاوتهاى فرهنكى، قومى و و اجتماعى اشاره بايد احتياط لازم توسط يُوهشخران و ونه

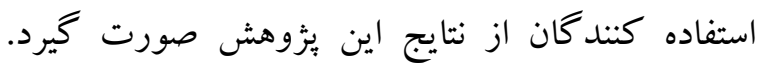

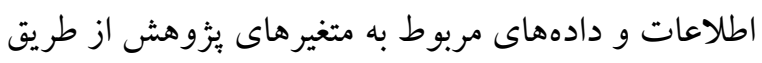
خود گزارشدهى شركت كنند گان و به وسيله برسشنامه جمع آورى شد كه اين شيوه تحت تأثير عوامل تأثير گذار

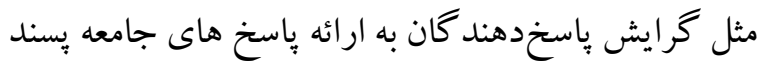
است. انجام اين يُزوهش در مرحله يس آزمون به يايان

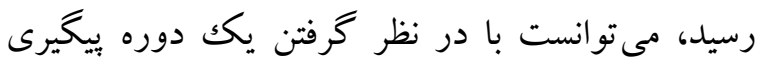
دستاوردهاى درمانى را در طول زمان نيز بررسى كرد؛ اما به دليل محدوديت زمانى و مكانى اين امر امكانيذير نبود. ئزوهش هاى مشابه در ديخر شهرها و فرهنگك هاى ديخر بر روى دختران دانش آموز ساير شهرها نيز اجرا شود تا نتايج يثزوششها با هم قابل مقايسه باشد. يثوهش هاى كاربردى با موضوعاتى مشابه در زمينه تأثير كروه درمانى تحليلى لاكانى بر ساير مشكلات نوجوانان مانند تابآورى، تحمل :يريشانى، تنظيم هيجان، استرس، افسردگى و اضطراب اجتماعى آنان صورت گيرد. انجام يثزوهشهاى در مورد مقايسه گروه درمانى تحليلى لاكانى با ساير روشهاى درمانى ماند درمان شناختى-رفتارى، آموزش يوكا مبتنى بر ذهن آكاهى، آموزش مديريت 


\section{References}

Allameh A, Shehni Yeilagh M, Haji Yakhchali A, Mehrabizadeh Honarmand M. (2016). The Comparison of Self -efficacy in Peer Interaction and Social Competence of Male Students with Aggressive and Normal Behaviors. Social Cognition, 4(2), 102-123. (In Persian)

Azimi D, Shariatmadar A. (2018). The Effect of Hardiness Training on Academic Self_ Efficacy and Social Acceptance Students. Educational Psychology, 14 (48), 87-103. (In Persian)

Beirami M, Hashemi T, Mirnasab M, Kolyaei L. (2018). Effectiveness of Social Problem Solving Training on the Components of Social competence in Students Victim of Bullying. Social Cognition, 7(1), 53-74. (In Persian)

Benner AD, Hou Y, \& Jackson KM. (2020). The Consequences of Friend-Related Stress Across Early Adolescence. The Joumal of Early Adolescence, 40(2), 249-272.

Bilir Seyhan G, Ocak Karabay S, Arda Tuncdemir TB, Greenberg, MT, Domitrovich C. (2019). The effects of Promoting Altemative Thinking Strategies Preschool Program on teacherchildren relationships and children's social competence in Turkey. International Journal of Psychology, 54 (1), 61-69.

Bryce CI, Alexander BL, Fraser AM, \& Fabes RA. (2020). Dimensions of hope in adolescence: Relations to academic functioning and well- being. Psychology in the Schools, 57(2), 171-190.

Cabaniss D, Chery S, Daglas C, Schwartz A. (2011). Analytical Psychotherapy: A Clinical Guide. Translated by Babak Roshanmoghadam and Mehmaz Mimoush. Tehran, Arjmand Press.

Camisasca E, Miragoli S, Di Blasio P, Feinberg M. (2019). Co-parenting mediates the influence of marital satisfaction on child adjustment: the conditional indirect effect by parental empathy. Journal of Child and Family Studies, 28(2), 519-530.

$$
\begin{aligned}
& \text { هستند، مورد توجه قرار گيرد. لازم به گفتن است }
\end{aligned}
$$

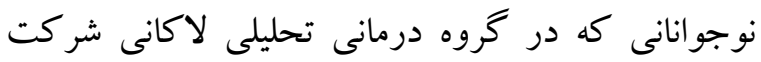

$$
\begin{aligned}
& \text { داشتند، با نشان دادن استقبال زياد براى شركت در اين } \\
& \text { جلسات، اصرار به ادامه جلسات داشتند و اظهار مىداشتند } \\
& \text { كه مايلاند اين درمان را به ديخران معرفى كنند؛ لذا با } \\
& \text { توجه به استقبال اين درمان از سوى نوجوانان به مدارس } \\
& \text { ييشنهاد مىشود از اين جلسات درمانى با استفاده از يكك } \\
& \text { روانشناس و مشاور مسلط به درمان مورد نظر به عنوان } \\
& \text { يكك فعاليت فوق برنامهاى در مدارس براى كمكك به } \\
& \text { بهبود يذيرش اجتماعى و كفايت اجتماعى دختران }
\end{aligned}
$$

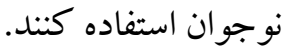

$$
\begin{aligned}
& \text { نتيجه كيرى } \\
& \text { نتايج نشان داد كه گروه درمانى تحليلى به كار رفته در } \\
& \text { اين يزوهش مىتواند همدلى، يذيرش اجتماعى و كفايت } \\
& \text { اجتماعى دختران نوجوان را بهبود بخشد. نتايج اين } \\
& \text { يثزوهش اثربخشى گرووه درمانى تحليلى را در بهبود } \\
& \text { همدلى، يذيرش اجتماعى و كفايت اجتماعى دختران } \\
& \text { نوجوان مورد تائيد قرار داد؛ بنابر اين با توجه به اثربخشى } \\
& \text { كروه درمانى تحليلى در محيطهاى مشاوره و رواندرمانى } \\
& \text { براى بهبود مشكلات دختران نوجوان از اهميت ويزٔاى } \\
& \text { برخوردار است. }
\end{aligned}
$$

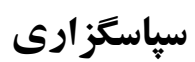

مقاله حاضر حاصل كار پِيان نامه كارشناسى ارشد نويسنده اول در رشته روانشناسى بالينى مصوب در دانشگاه آزاد اسلامى واحد ساوه است. نويسند گان بدين

وسيله از تمامى دانش آموزانى كه در اين بثروهش شركت كردند صميمانه تشكر مىنمايد. 
Carrizales A, Perchec C, Lannegrand-Willems L. (2019). Brief report: How many dimensions in the prosocial behavior scale? Psychometric investigation in French -speaking adolescents. European Joumal of Developmental Psychology, 16(3), 340-348.

Crowne DP, Marlowe D. (1960). A new scale of social desirability independent of psychopathology. Journal of consulting psychology, 24 (4), 349.

Dasht Bozorgi Z, Shamshirgaran M. (2018). Effectiveness of Positive Training on Social Competence and Health Hardiness in Nurses. Positive Psychology, 4(2), 13-24. (In Persian)

Egbe IB, Augustina OO, Itita EV, Patrick AE, \& Bassey OU. (2020). Sexual Behaviour and Domestic Violence among Teenage Girls in Yakurr Local Government Area, Cross River State, Nigeria. Academic Joumal of Interdisciplinary Studies, 9(2), 101-115.

Espelage DL, Holt MK. (2001). Bullying and victimization during early adolescence: Peer influences and psychosocial correlates. Joumal of Emotional Abuse, 2(2-3), 123-142.

Felner RD, Lease AM, Phillips RS. (1990). Social competence and the language of adequacy as a subject matter for psychology: A quadripartite tri-level framework. The development of social competence in adolescence, 245-264.

Fernandes C, Monteiro L, Santos AJ, Fernandes M, Antunes M, Vaughn BE, Veríssimo $\mathrm{M}$. (2019). Early father-child and mother-child attachment relationships: contributions to preschoolers' social competence. Attachment human development, 1-18.

Fernandez YM, \& Marshall WL. (2003). Victim empathy, social self-esteem, and psychopathy in rapists. Sexual Abuse: A Journal of Research and Treatment, 15(1), 11-26.

Ferreira M, Aguiar C, Correia N, Fialho M, Pimentel JS. (2019). Friendships and Social Acceptance of Portuguese Children With Disabilities: The Role of Classroom Quality, Individual Skills, and Dosage. Topics in Early Childhood Special Education, 39(3), 183-195.
Homer S. (2004). Jacques lacan. Translated by Mohammad Ali Jafari and Seyed Mohammad Ibrahim Tahaee. Tehran: Qoqnoos Press.

Hukkelberg S, Keles S, Ogden T, Hammerstrom K. (2019). The relation between behavioral problems and social competence: A correlational Meta-analysis. BMC psychiatry, 19(1),354.

Jolliffe D, Farrington DP. (2006). Development and validation of the Basic Empathy Scale. Journal of adolescence, 29 (4), 589-611.

Kaji Isfahani S, Arefi M, Aqaei Joshaghani A, Asli Azad M, Farhadi T. (2017). Comparison of Cognitive Empathy in Students with Relational and Explicit Aggression. jcmh. 4 (2), 116-124. (In Persian)

Khanjani Z, Bahadorikhosroshhi J. (2017). Investigation of empathy development, intemalization and extemalizing disorders in male and female students 5 to 11 years. Counseling Culture and Psycotherapy, 8(30), 195-218. (In Persian)

Khoshravesh S, Khosrojavid M, Hoseyn khanzade A. (2015). Efficacy of emotion regulation training on social acceptance and empathy of students with dyslexia. Joumal of Leaming Disabilities, 5(1), 32-46. (In Persian)

King BM, Duncan LM, Clinkenbeard KM, Rutland MB, Ryan KM. (2019). Social Desirability and Young Men's Self-Reports of Penis Size. Journal of sex marital therapy, 1-4.

Martinac Dorcic T, Smojver-Azic S, Roncevic Zubkovic B, Kolic-Vehovec S. (2019). Determinants of Helping the Victim in Situations of Peer Violence. Psychological Topics, 28(3), 681-700.

Mewton L, Shaw B, Slade T, Birrell L, Newton NC, Chapman C, \& Teesson M. (2020). The comorbidity between alcohol use and intemalising psychopathology in early adolescence. Mental Health \& Prevention, 17(1), 1-10.

Moosaviyaan S, Talaa'ee E, Fardaanesh H, Bakhtiyaari A. (2019). A Framework for CompassionBased Teaching. QJOE, 35 (3), 9-34. (In 
Persian)

Nurahman NI, Isnaeni W, Ellianawati E. (2020). Analysis of Communication Skills and Empathy of Fifth-Grade Students of Elementary Schools through ICT-based Learning. Joumal of Primary Education, 321327.

Osmani H, Shokri L. (2019). Effectiveness of unified trans-diagnostic treatment on emotion's cognitive regulation and cognitive empathy of students with extemalized behavior disorder.Empowering Exceptional Children, 10(1), 125-136. (In Persian)

Park KH, Kim DH, Kim SK, Yi YH, Jeong JH, Chae J, Roh H. (2015). The relationships between empathy, stress and social support among medical students. Intemational joumal of medical education, 6, 103.

Pascual-Sagastizabal E, Del Puerto N, Cardas J, Sanchez-Martin JR, Vergara AI, Azurmendi A. (2019). Testosterone and cortisol modulate the effects of empathy on aggression in children. Psychoneuroendocrinology, 103, 118-124.

Petranovich CL, Walz NC, Staat MA, Chiu CYP, Wade SL. (2016). Structural language, pragmatic communication, behavior, and social competence in children adopted intemationally: A pilot study. Applied Neuropsychology: Child, 1-12.

Rieffe C, Ketelaar L, Wiefferink CH. (2010). Assessing empathy in young children: Construction and validation of an Empathy Questionnaire (EmQue). Personality and individual differences, 49 (5), 362-367.

Salibi J, Modaresi G. (2016). Studying the Relationship between General Health and Occupational Burnout and Social Competency of Primary SchoolFemale Teachers of Tehran (Academic year of 2013-14). Women Studies, 7(15), 127154. (In Persian)

Samadifard H, Narimani M. (2017). Bullying in high school male students: The role of perception of interaction, support and social acceptance. Journal of Social Psychology, 5(45), 83-94. (In Persian)
Sarbescu P, Costea I, Rusu S. (2012). Psychometric properties of the marlowe-crowne social desirability scale in a romanian sample.Procedia-Social and Behavioral Sciences, 33, 707-711.

Sarvarian Z, Taghizadeh M, Meto S. (2016). Effect of Logo Therapy on Social Competence in Adolescents. Social Psychology Research, 6(21), 33-45. (In Persian)

Schweizer S, Gotlib IH, \& Blakemore SJ. (2020). The role of affective control in emotion regulation during adolescence. Emotion, 20(1), 80-90.

Sediq Karaj N, Aqdasi A. (2017). Investigating the effectiveness of social skills training on academic adjustment, academic performance and social adequacy in female high school students in Tabriz. Quarterly Joumal of Modern Psychological Ideas. 1(4), 1-11. (In Persian)

Shariatmadar A, Poorgravand S. (2014). Comparison of sensation seeking and social competence of girls living in well-being boarding centers and girls adopted by families. Counseling Culture and Psycotherapy, 5(20), 95-112. (In Persian)

Szuster A, Jarymowicz M. (2020). Human empathy of automatic vs. reflective origin: Diverse attributes and regulative consequences. New Ideas in Psychology, 56, 100748.

Tarantino L, De Gasperis G, Mascio TD, Pino MC. (2019, November). Immersive applications: what if users are in the autism spectrum?. In The 17th International Conference on Virtual-Reality Continuum and its Applications in Industry (p. 32). ACM.

Tashkeh M, Davazdahemamy MH, Bazani M, shahhosseni M, Mostafalo T. (2019), The Effectiveness of Emotional Schema Therapy on Social Acceptance and Bullying Behavior in Teenagers with Post-Traumatic Stress Disorder. Hrjbaq, 4(2), 88-95. (In Persian)

Tiwari P, Bhat AK. (2020). The Effect of Emotional Intelligence, Empathy and Perceived Social Pressure on Predicting Social Entrepreneurial Intention: A Field Research. In Methodological Issues in Social Entrepreneurship Knowledge and Practice 
(pp. 137-158). Springer, Singapore.

Torkman Malayeri M, Sheikholeslami R. (2019).

Empathy and Pro-Social Behavior. The Mediating Role of Moral Emotions. Jouranal

Devolopmental Psychology Iranian

Psychologist, 15(59), 261-272. (In Persian)

Turner IN, Foster JD, Webster GD. (2019). The Dark Triad's inverse relations with cognitive and emotional empathy: High-powered tests with multiple measures. Personality and Individual Differences, 139, 1-6.

Vaziri S, Lotfi Azimi A. (2011). The effect of empathy traiing in decreasing adolescents aggression. Jouranl Developmental Psychology, 8(30), 167-175. (In Persian)

Vera Cruz G, Mullet E. (2019). Empathy and forgiveness among Mozambican wives. International Perspectives in Psychology: Research, Practice, Consultation, 8(3), 124.

Wang G, Mearns J, Yang X, Han P, Catanzaro SJ. (2019). Measuring generalised expectancies for negative mood regulation in China: The Chinese language Negative Mood Regulation scale. International Journal of Psychology, 54 (2), 223-231.

Yang C, Zhu YL, Xia BY, Li YW, Zhang J. (2020). The effect of structured empathy education on empathy competency of undergraduate nursing interns: A quasi-experimental study. Nurse education today, 85, 104296.

Zachrisson HD, Janson H, Lamer K. (2019). The Lamer Social Competence in Preschool (LSCIP) Scale: Structural Validity in a Large Norwegian Community Sample. Scandinavian Joumal of Educational Research, 63(4), 551-565. 